\title{
Synthesis and HIV-1 Integrase Inhibitory Activities of 4-Hydroxy-5-azacoumarin 3-Carboxamides
}

\author{
Seung Uk Lee, Jang Hyun Park, ${ }^{\dagger}$ Tae Hoon Kwon, ${ }^{\ddagger}$ Yeong Jae Yoo,,$\stackrel{+}{+}$ \\ Jae Yeol Lee, ${ }^{8}$ Cha-Gyun Shin, ${ }^{\#}$ Kyung Ho Yoo, and Yong Sup Lee ${ }^{+*}$ \\ $\div$ Life. Sciences Research Division. Korea Institule of Science \& Techology, Seoul 130-650, Korea \\ ${ }^{*}$ Kyang Hee East-West Pharmaceutical Research Instinte and Department of Pharmaceutical Sciences \& Department of Life and

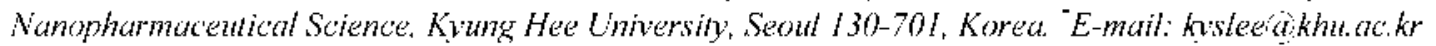 \\ ${ }^{\$}$ Research Institute of Basic Science and Department of Chemisin Sciences \& Department of Life and Nanophamacentical \\ Science, Kyung Hee University, Seoul 130-701, Korea \\ Department of Biotechnologv. Chung-ing University. An-Sung, Kyung-gi 456-756. Korea \\ Recened.June 4. 2007
}

\begin{abstract}
Recently, it has been reported that the inhibition of the strand transfer function of IIIV-I integrase is necessary to obtain significant antiviral activity. $\Lambda$ ccordingly, several compounds typified by aryl 1.3-diketo acids that can inhibit strand transfer reaction of IIIV-1 IN have been identified. In this work, we synthesized new 4hydroxy-5-azacoumarin-3-carbox(thio)amides (1a-h) and evaluated for the inhibition of IIIV-1 IN strand transfer reaction with a brief SAR. Among synthesized, compound le was the most potent IIIV-I IN inhibitor with equipotent activity to that of L-708,906. Therefore, the 4-hydroxy-5-azacoumarin ring can be considered as a new scaffold in designing more potent of HIV-1 IN inhibitors for treatment of $\Lambda$ IDS.
\end{abstract}

Key Words : HIV-I integrase inhibitor, Strand transfer, 4-Hydroxy-5-azacoumarin

\section{Introduction}

Human immunodeficiency virus (HIV) is the probable causative agent of acquired immune deficiency syndrome (AIDS), which is one of the world's most serious health problems. ' The number of people living with HIV/AIDS is estimated to 38 million and approximately 3 million AIDS death were reported in 2003 . Several biological processes in the life cycle of this virus have been targeted for anti-HIV therapy. Accordingly, a number of anti-HIV drugs targeting key enzymes for viral replication; HIV reverse transcriptase and HIV protease, has been approved for the treatment of $\mathrm{HIV}$ infected patients. However, since the efficiency of these drugs is limited by the emergency of HIV mutants and adverse side effects further development of different type of drug is continuously required. Another important step in the replication of HIV is integration of the viral DNA into the host cell DNA. ${ }^{3}$ This step is catalyzed by the viral enzyme HIV integrase (IN). HIV IN catalyzes two distinct reactions, known as terminal cleavage at each 3 ' end of the proviral DNA removing a pair of bases and strand transfer which results in the joining of each 3 ' end to 5 -phosphates in the target DNA. Such integration is essential for the production of progeny viruses. As these reactions are essential for the life cycle of viruses, integrase represents an attractive target for treatment of HIV infections. ${ }^{4.6} \mathrm{HIV}$ IN has also been recognized as a safe target against HIV because there are no similar enzymes involved in human cellular function.? Recently, several aryl 1,3-diketo acids as exemplified by compounds $I$ that can inhibit strand transfer reaction of HIVI IN have been identified as potent anti-HIV agent (Figure 1). ${ }^{8}$ The 1,3-diketo acid moiety of the compound $\mathbf{I}$ has been postulated to be an essential part for the inhibitory activity of HIV-I IN strand transfer since these part is believed to interact with catalytically important $\mathrm{Mg}^{2-}$ in the active site of HIV-I IN step. Accordingly, the variations of structural features of aryl 1,3-diketo acids have been made leading to 8-hydroxy-1,6-naphthyridine II, which mimic the metal cation interaction site of the 1,3-diketo acid pharmacophore. 10.11

In our continued study on the development of HIV-I IN inhibitors, ${ }^{12}$ we here disclose the synthesis of 4-hydroxy-5azacoumarin carboxamides or carboxthioamides 2, which have an azacoumarin ring as a new scaffold of HIV-I IN inhibitors. We envisioned that 4-hydroxy-5-azacoumarin<smiles>O=C(O)CC(=O)c1cc(OCc2ccccc2)cc(OCc2ccccc2)c1</smiles><smiles></smiles>

Figure 1. Folution of coumarin IIIV-I integrase inhibitor from 1,3-dikelo acid. 
<smiles>CCOC(=O)C(OCC)OCC</smiles>

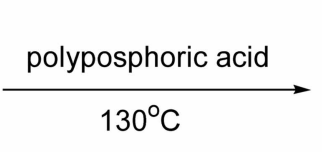

$65 \%$<smiles>O=c1cc(O)c2ncccc2o1</smiles>

4<smiles>CCOCC(OCC)C(=O)c1ncccc1OCC</smiles>

2<smiles>CCOC(=O)C(O)=C(O)c1ncccc1O</smiles>

3

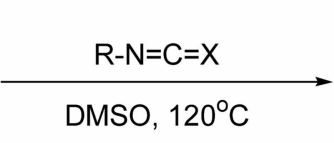

DMSO, $120^{\circ} \mathrm{C}$<smiles>[R]NC([X])c1c(O)c2ncccc2oc1=O</smiles>

1

Scheme 1. Synthesis of 4-hydroxy-5-azacoumarin-3-carbox(thio)anides.

ring can mimic HIV-] [N inhibitory 8-hydroxy-l,6-naphthyridines II since they have the same functional groups that may bind with $\mathrm{Mg}^{2-}$. Furthermore, it is anticipated that additional hydrogen bonds may be possible via interaction of carbonyl oxygen of lactone ring in 2 with polar residues in the active site of HIV-I IN. To investigate the influence of substituentes on inhibitory effect we set the variations at amide part in the design of inhibitors.

\section{Results and Discussion}

Chemistry. The chemistry used to prepare the 4-hydroxy- 5-azacoumarin derivatives $\mathbf{1} \mathbf{a}-\mathbf{h}$ is illustrated in Scheme $\mathbf{l}$. The target compounds were synthesized by reaction of 4 hydroxy-5-azacoumarin (4) with aryl isocyanate or aryl isothiocyanates. The required intermediate 4 was prepared by the slight modification of literature procedure. ${ }^{13}$ Reaction of 2-hydroxypicolinic acid with ethyl chloroformate followed by condensation with ethyl ethoxymagnesium malonate afforded compound 2 . This compound was directly subjected to partial hydrolysis condition: treatment of potassium carbonate in water to provide a hemiester of hydroxypicolnoylmalonic acid (3) in 35\% yield for two steps. 5Azacoumarin ring was constructed by heating 3 at $130^{\circ} \mathrm{C}$ in

Table 1. HIV-I IN inhibitory activity of 4-hydroxy-5-azacoumarin-3-carbox(thio)amides (1a-h)

\begin{tabular}{|c|c|c|c|c|c|}
\hline Inhibitors & Structures & $\begin{array}{l}\text { Strand transiler } \\
(\mathrm{IC} ; \mathrm{s} \cdot \mu \mathrm{M})\end{array}$ & Inhibitors & Structures & $\begin{array}{c}\text { Strand transfer } \\
(\mathrm{K} C, \mu \mathrm{M})\end{array}$ \\
\hline $1 a$ & & 15.9 & $1 f$ & & $>300$ \\
\hline $1 \mathrm{~b}$ & & 6.7 & $1 \mathrm{~g}$ & & $>300$ \\
\hline 1c & & 35.7 & $1 \mathrm{~h}$ & & $>300$ \\
\hline $1 d$ & & 12.3 & I & & 5.5 \\
\hline 10 & & $>300$ & & & \\
\hline
\end{tabular}


polyphosphoric acid to give 4 in $65 \%$ yield. The 3 -carboxamides or thioamides of azacoumarin (1) $\mathbf{a}-\mathbf{h})$ were obtained by the thermal reaction of 4 with aryl isocayanates or aryl isothiocyanates at $120{ }^{\circ} \mathrm{C}$ in DMSO containing triethylamine. ${ }^{1 \dot{4}}$

Biological activity. The resulting 4-hydroxy-5-azacoumarin-3-carbox(thio)anides (1a-h) were assayed in vitro for inhibition of HIV-1 IN strand transfer (Table 1). ${ }^{1516}$ To compare the inhibitory activity, L-708.906 (I) in Figure 1 was prepared by using a known procedure ${ }^{z}$ and the activity data was included as a reference in the table. $N$-Benzylcarboxamide derivatives of azacoumarin (1a-d) showed moderate to good inhibitory activities for HIV-I IN strand transfer reaction. Among tested, 4-fluorobenzyl-substituted azacoumarin (1b) showed the most potent inhibitory activity $\left(\mathrm{IC}_{50}=6.7 \mu \mathrm{M}\right)$ comparable to that of L-708.906 (I. IC $\mathrm{IC}_{50}=$ $5.5 \mu \mathrm{M})$. On the other hand, $N$-phenyl-carboxamide (1e) and thiocarboxamide derivatives (1g-h) exhibited no activity under the concentration of $300 \mu \mathrm{M}$ indicating that anide carbonyl and benzyl substituent in amide part are important for inhibition of HIV-I IN strand transfer reaction.

In conclusion. 4-hydroxy-5-azacoumarin-3-carbox(thio)anides (1a-h) as novel HIV-l IN inhibitors were synthesized and evaluated for the inhibition of HIV-I IN strand transfer reaction with a brief SAR. Among synthesized. compound $1 \mathrm{~b}$ was the most potent HIV-1 IN inhibitor with equipotent activity to that of L-708.906. Therefore. the 4hydroxy-5-azacoumarin ring can be considered as a new scaffold in designing more potent of HIV-1 IN inhibitors for treatment of AIDS.

\section{Experimental Section}

Chemistry: general. All reactions were carried out under nitrogen atmosphere. Flash column chromatographies were performed with Merck Kiesegel 60 Art 9385 (230-400 mesh). All solvents used were purified according to standard procedures. ${ }^{1} \mathrm{H}$ and ${ }^{13} \mathrm{C}$ NMR spectra were recorded on a Gemini Varian-300 (300 and $75 \mathrm{MHz}$, respectively): chemical shifts are expressed value (ppm) and coupling constants $(J)$ in $\mathrm{Hz}$.

Ethyl hemiester of 3-hydroxypicolinoylmalonic acid (3). A solution of 3-hydroxypicolinic acid (13 g. $93.5 \mathrm{mmol}$ ) and $\mathrm{Et}_{3} \mathrm{~N}(26.1 \mathrm{~mL}, 187.2 \mathrm{~mm}$ ol) in the mixed solvent of 1.4-dioxane and toluene (1:1. $160 \mathrm{~mL})$ was stirred for 30 min. This solution was cooled to $-5{ }^{\circ} \mathrm{C}$ and treated with a solution ethyl chloroformate $(17.9 \mathrm{~mL} .187 .5 \mathrm{mmol})$ in toluene $(40 \mathrm{~mL})$. After stirring at $0^{\circ} \mathrm{C}$ for $2 \mathrm{~h}$, a solution of ethyl ethoxymagnesium malonate (32 $\mathrm{g}, 140.3 \mathrm{mmol}$ ) in toluene $(50 \mathrm{~mL})$ was added to the mixture. The mixture was further stirred overnight at $\mathrm{rt}$ and then acidified to $\mathrm{pH} 3 \mathrm{by}$ addition of $3 \mathrm{~N} \mathrm{HCl}$. The aqueous solution was stirred $30 \mathrm{~min}$ and extracted with a mixture of benzene and chloroform (1:1). The organic layer was dried over $\mathrm{MgSO}_{4}$, evaporated under reduced pressure to give a brown oily residue. This residue $(\mathrm{ca} .33 \mathrm{~g})$ was dissolved in water $(100 \mathrm{~mL})$ and treated with $\mathrm{K}_{3} \mathrm{CO}_{3}(19 \mathrm{~g}$. $140.3 \mathrm{mmol})$. The reaction mixture was stirred at $80^{\circ} \mathrm{C}$ for $4 \mathrm{~h}$. After the mixture was completely cooled to $\mathrm{rt}$ and the resulting orange colored precipitate was filtered. The filter cake was washed with a small quantity of methanol and acetone. The washed filter cake was dissolved in water $(100 \mathrm{~mL})$ and acidified to $\mathrm{pH} \mathrm{l}$ 2 by addition of $3 \mathrm{~N} \mathrm{HCl}$. An orange colored precipitate of flakes was filtered, washed with water, and dried in wacho to give $3\left(8.28\right.$ g. $35 \%$ ) as a yellow solid. ${ }^{1} \mathrm{H}$ NMR (DMSO- $d_{6}$ ) $\delta 8.59(\mathrm{lH}, \mathrm{d}, J=5.7 \mathrm{~Hz}$, pyridine- $H 6), 8.12(\mathrm{lH} . \mathrm{d} . J=8.4$ Hz. pyridine- $H f$ ). 7.98 (IH. dd, $J=5.7 .8 .4 \mathrm{~Hz}$. pyridine$H 7) .4 .12\left(2 \mathrm{H} . \mathrm{q}, J=6.6 \mathrm{~Hz},-\mathrm{OCH}_{2} \mathrm{CH}_{3}\right) .1 .22(2 \mathrm{H}, \mathrm{t} . J=$ $6.6 \mathrm{~Hz},-\mathrm{OCH}_{2} \mathrm{CH}_{3}$ ): ${ }^{12} \mathrm{C}$ NMR (DMSO- $\left.d_{6}\right) \delta 209.0 .179 .6$, 163.4. 163.1. 152.5. 139.3. 129.9. 125.4. 84.2.58.4. 15.0.

4-Hydroxy-5-azacoumarin (4). A mixture of $3(7.5 \mathrm{~g}$. $29.6 \mathrm{mmol})$ and poly phosphoric acid $(45.0 \mathrm{~g}$ ) were heated at $127^{\circ} \mathrm{C}$ until no more gas evolved. After cooling to rt. the mixture was treated with water and stirred to dissolve polyphosphoric acid. Sodium hydrogen carbonate was slowly added to the mixture with stirring until the solution become $c a . \mathrm{pH} 3$. The resulting precipitate was filtered and the filtered cake was washed with water and $\mathrm{MeOH}$, and dried to give $4\left(3.19 \mathrm{~g} .65 \%\right.$ ). ${ }^{1} \mathrm{H}$ NMR (DMSO- $\left.c_{6}\right) \delta 8.63$ (lH. d. $J=4.5 \mathrm{~Hz}, H 6), 7.89$ (1H. d. $J=8.7 \mathrm{~Hz}, H 8), 7.72$ (lH. dd. $J=8.7,4.5$ Hz. $H 7$ ). 5.83 (lH. s, $H 3$ ),${ }^{13} \mathrm{C}$ NMR (DMSO- $d_{6}$ ): 166.1, 161.8. 150.9. 146.1, 133.9, 128.0, 125.4. 95.0 .

General procedure for the synthesis of compounds 1ah. Solutions of $4(300 \mathrm{mg} .1 .84 \mathrm{mmol})$, triethylamine $(0.77$ $\mathrm{mL}, 5.52 \mathrm{mmol}$ ) and 1 equivalent of arylisocyanate or arylisothiocyanate in dimethylsulfoxide (DMSO, $5 \mathrm{~mL}$ ) were heated at $95^{\circ} \mathrm{C}$ ovenight. After cooling to it. the mixture was treated with $3 \mathrm{~N} \mathrm{HCl}$ and extracted with ethyl acetate. The organic layer was dried over anhydrous $\mathrm{MgSO}_{4}$, concentrated. and purified by recrystallization from methanolchloroform and/or flash column chromatography $\left(\mathrm{CH}_{3} \mathrm{OH} /\right.$ $\mathrm{CH}_{2} \mathrm{Cl}_{2}=1: 10$ ) to provide $\mathbf{1 a}-\mathbf{h}$.

3-( $N$-Benzylcarbamoyl)-4-hydloxy-5-azacoumarin (1a): The treatment of $4(300 \mathrm{mg} .1 .84 \mathrm{mmol})$ with benzylisocyanate $(0.23 \mathrm{~mL}, 1.84 \mathrm{mmol})$ according to the general procedure provided the desired product $1 \mathrm{a}(81 \mathrm{mg} .15 \%)$. ${ }^{\mathrm{H}} \mathrm{H}$ NMR (DMSO- $\left.d_{6}\right) \delta 9.76\left(1 \mathrm{H}, \mathrm{t} . J=4.6 \mathrm{~Hz} .-\mathrm{CONHCH}_{2}-\right)$, $8.73(1 \mathrm{H}, \mathrm{d} . J=3.3 \mathrm{~Hz} . H 6) .7 .98(1 \mathrm{H} . \mathrm{d} . J=8.4 \mathrm{~Hz}, H 8)$. $7.83(1 \mathrm{H}$. dd. $J=8.4 .3 .3 \mathrm{~Hz} . H 7) .7 .39(5 \mathrm{H}, \mathrm{m}$, phenyl- $H$ ). 4.63 ( $2 \mathrm{H} . \mathrm{d} . J=4.6 \mathrm{~Hz},-\mathrm{NHC} H_{2} \mathrm{Ph}$ ): ${ }^{13} \mathrm{C}$ NMR (DMSO- $c_{5}$ ) $\delta 176.3 .170 .6,161.2 .151 .5,147.7$. 138.6, 133.3. 130.0. $129.2,128.3 .128 .0,126.0,94.7,43.4$.

3-( $N$-(4-Fluorobenzyl)carbamoyl)-4-hydroxy-5-azacoumarin (1b): The treatment of $4(150 \mathrm{mg} .0 .92 \mathrm{mmol})$ with 4 fluorobenzylisocyanate $(0.12 \mathrm{~mL} .0 .92 \mathrm{mmol}))$ according to the general procedure provided the desired product $1 \mathrm{~b}(122$ mg. $42 \%)$. ${ }^{1} \mathrm{H}$ NMR $\left(\mathrm{CDCl}_{3}\right) \delta 9.54\left(\mathrm{lH}, \mathrm{s}, \mathrm{CO}-\mathrm{N} H-\mathrm{CH}_{2}\right)$, $8.80(1 \mathrm{H}, \mathrm{d} . J=3.9 \mathrm{~Hz} . H 6) .7 .75(1 \mathrm{H} . \mathrm{d}, J=8.4 \mathrm{~Hz}, H 8)$, $7.68(1 \mathrm{H}$. dd. $J=8.4 .4 .5 \mathrm{~Hz} . H 7) .7 .38(2 \mathrm{H}$. two d. $J=8.4$. $5.4 \mathrm{~Hz}$, phenyl- $H) .7 .10(2 \mathrm{H}$, two d. $J=8.7,9.0 \mathrm{~Hz}$, phenyl$H) .67\left(2 \mathrm{H}\right.$. two s. $-\mathrm{NHCH}_{2}$-phenyl): ${ }^{13} \mathrm{C}$ NMR (DMSOdb) $\delta 164.6,164.2 .150 .1,144.6,132.3,128.5 .126 .3,100.7$, 60.9. 14.0 
3-( $N$-(4-Bromobenzyl)carbamoyl)-4-hydroxy-5-azacoumarin (1c): The treatment of $4(250 \mathrm{mg} .1 .53 \mathrm{mmol})$ with 4 bromobenzylisocyanate $(0.2 \mathrm{lmL} .1 .53 \mathrm{mmol})$ according to the general procedure provided the desired product 1c ( 154 mg. $27 \%$ ). ${ }^{1} \mathrm{H}$ NMR (DMSO- $\left.d_{6}\right) \delta 9.80(1 \mathrm{H}$, br t. $J=6 \mathrm{~Hz}$. $. \mathrm{CONHCH}_{2}-8.73(\mathrm{lH} . \mathrm{d} . J=4.2 \mathrm{~Hz}, H 6), 7.98(\mathrm{lH} . \mathrm{d}, J=$ $8.4 \mathrm{~Hz}, H 8), 7.84(\mathrm{lH} . \mathrm{dd}, J=8.4,4.2 \mathrm{~Hz} . H 7), 7.57(2 \mathrm{H}$. d. $J=8.1 \mathrm{~Hz}$, phenyl $-H), 7.36(2 \mathrm{H}, \mathrm{t} . J=8.1 \mathrm{~Hz}$, phenyl- $H$ ). 4.59 (2H. d. $J=6 \mathrm{~Hz},-\mathrm{NHCH}_{2}-{ }^{13} \mathrm{C}$ NMR (DMSO- $\left.d_{6}\right) \delta$ 176.20, 170.7. 161.1. 151.5, 147.7, 138.2, 133.3. 132.1. 130.6. 130.0, 126.0, 121.0,94.9. 42.8 .

3-(N-(4-Methylbenzyl)carbamoyl)-4-hydroxy-5-azacoumarin (1d): The treatment of $4(300 \mathrm{mg}, 1.84 \mathrm{mmol})$ with $4-$ methylbenzy lisocyanate $(0.27 \mathrm{~mL}, 1.84 \mathrm{mmol})$ according to the general procedure provided the desired product $1 d$ ( 80 mg. $14 \%$ ). ${ }^{1} \mathrm{H}$ NMR (DMSO-d $\left.d_{6}\right) \delta 9.70(\mathrm{lH}$. br $\mathrm{t}, J=6.0 \mathrm{~Hz}$ $\left.-\mathrm{CONHCH}_{2}-\right), 8.73(\mathrm{lH} . \mathrm{d} . J=4.2 \mathrm{~Hz}, H 6), 7.97(1 \mathrm{H} . \mathrm{d}, J=$ $8.4 \mathrm{~Hz}, H 8), 7.83(\mathrm{lH} . \mathrm{dd}, J=8.4,4.2 \mathrm{~Hz} . H 7), 7.28(2 \mathrm{H}$. d. $J=7.6 \mathrm{~Hz}$. phenyl- $H), 7.18(2 \mathrm{H}, \mathrm{d}, J=7.6 \mathrm{~Hz}$. phenyl- $H)$. $4.58(2 \mathrm{H} . \mathrm{d}, J=6.0 \mathrm{~Hz},-\mathrm{NHCH}=$-phenyl). $2.30(3 \mathrm{H}, \mathrm{s}$. $\mathrm{CH}_{3}$ phenyl-); ${ }^{13} \mathrm{C}$ NMR (DMSO- $\left.d_{6}\right) \delta 176.4 .170 .5$. 161.2. 151.5. 147.7. 137.2, 135.5, 133.3. 130.0, 129.8, 128.4. 126.0. 94.6. 43.1. 21.4 .

3-( $N$-Phenylcarbamoyl)-4-hydroxy-5-azacoumarin (1e): The treatment of $4(300 \mathrm{mg}, 1.84 \mathrm{mmol})$ with pheny lisocyanate $(0.21 \mathrm{~mL} .1 .84 \mathrm{mmol})$ according to the general procedure provided the desired product $1 \mathrm{e}(110 \mathrm{mg} .21 \%)$. ${ }^{1} \mathrm{H}$ NMR (DMSO- $\left.d_{6}\right) \delta 11.10(1 \mathrm{H}, \mathrm{s}$. -CONH-phenyl), 8.77 $(1 \mathrm{H}, \mathrm{d}, J=4.5 \mathrm{~Hz} . H 6) .8 .06(1 \mathrm{H} . \mathrm{d}, J=8.4 \mathrm{~Hz}, H 8), 7.88$ $(1 \mathrm{H}, \mathrm{dd}, J=8.4 .4 .5 \mathrm{~Hz}, H 7), 7.69(2 \mathrm{H}, \mathrm{d} . J=7.8 \mathrm{~Hz}$. phenyl- $H 2,6), 7.45(2 \mathrm{H}$, t. $J=7.5 \mathrm{~Hz}$, phenyl- $H 3,5), 7.24$ $\left(1 \mathrm{H}, \mathrm{t}, J=7.4 \mathrm{~Hz}\right.$, phenyl- $H+$ ); ${ }^{13} \mathrm{C}$ NMR (DMSO- $\left.d_{6}\right) \delta$ 174.4. 168.0. 147.7, 137.1, 130.2. 129.9, 126.2, 126.0. 121.8.97.0.

3-( $N$-Phenylthiocarbamoyl)-4-hydroxy-5-azacoumarin (1f): The treatment of $+(300 \mathrm{mg} .1 .84 \mathrm{mmol})$ with phenylisothiocyanate $(0.22 \mathrm{~mL} .1 .84 \mathrm{mmol})$ according to the general procedure provided the desired product $1 \mathrm{f}(120 \mathrm{mg}$. $22 \%$ ). ${ }^{\mathrm{H}} \mathrm{H}$ NMR (DMSO- $d_{6}$ ) $\delta 13.02$ (1H. s. -CSNH-phenyl). $8.68(1 \mathrm{H}$, d. $J=4.4 \mathrm{~Hz}, H 6) .7 .92(1 \mathrm{H}, \mathrm{d} . J=8.3 \mathrm{~Hz}, H 8$ ). $7.75(1 \mathrm{H}$. dd. $J=8.3 .4 .4 \mathrm{~Hz}, H 7), 6.75-7.12(5 \mathrm{H}$. m. phenyl$H$ ) ${ }^{13} \mathrm{C}$ NMR (DMSO- $d_{6}$ ) $\delta 178.4,164.6,158.8,150.4$. $147.2 .137 .2,136.5,129.2,129.0,126.6,126.0,124.2 .91 .6$.

3-( $N$-Benzylthiocarbamoyl)-4-hydroxy-5-azacoumarin (1g): The treatment of $4(300 \mathrm{mg} .1 .84 \mathrm{mmol})$ with benzylisothiocyanate $(0.25 \mathrm{~mL} .1 .84 \mathrm{mmol})$ according to the general procedure provided the desired product $1 \mathrm{~g}(180 \mathrm{mg}$. $31 \%$ ). ${ }^{~} \mathrm{H}$ NMR (DMSO- $d_{6}$ ) $\delta 11.15$ (lH. br t. $J=5.4 \mathrm{~Hz}$. - $\mathrm{CSNHCH}_{2}$ ). 8.71 (lH. d. $J=4.5 \mathrm{~Hz} . H 6$ ). 7.99 (lH. d. $J=$ $8.4 \mathrm{~Hz}, H 8) .7 .8 \mathrm{I}(1 \mathrm{H}, \mathrm{dd}, J=8.4 .4 .5 \mathrm{~Hz}, H 7) .7 .36(5 \mathrm{H}, \mathrm{m}$. phenyl- $H$ ) 4.94 (2H. d. $J=5.4 \mathrm{~Hz}$. $-\mathrm{NHCH}$-phenyl): ${ }^{13} \mathrm{C}$ NMR (DMSO- $\left.d_{6}\right) \delta 190.3,162.7,159.9,149.8 .146 .6$. 137.3. 133.5, 129.1, 128.8, 128.4, 128.0, 125.7, 109.0. 48.6.

3-( $N$-(4-Fluorobenzy) thiocarbamoyl)-4-hydroxy-5-azacoumarin (1h): The treatment of $4(300 \mathrm{mg} .1 .84 \mathrm{mmol})$ with 4-fluorophenylisothiocyanate $(0.32 \mathrm{~mL}, 1.84 \mathrm{mmol})$ according to the general procedure provided the desired product $1 \mathrm{f}(240 \mathrm{mg}, 40 \%) .{ }^{1} \mathrm{H}$ NMR (DMSO- $\left.d_{6}\right) \delta 11.12$ (lH. br t. $J=5.4$ Hz. $-\mathrm{CSNHCH}=), 8.71(\mathrm{lH}, \mathrm{d}, J=4.5 \mathrm{~Hz}$, $H 6$ ). 7.99 (l H. d. $J=8.1 \mathrm{~Hz}, H 8), 7.81(1 \mathrm{H}, \mathrm{dd} . J=8.1 .4 .5$ Hz. $H 7), 7.48(2 \mathrm{H}, \mathrm{m}$, phenyl $-H), 7.22(2 \mathrm{H} . \mathrm{m}$, phenyl $-H)$, $4.93\left(2 \mathrm{H}, \mathrm{d}, J=6.0 \mathrm{~Hz}\right.$. $-\mathrm{NHCH} \mathrm{H}_{2}$-phenyl): ${ }^{13} \mathrm{C}$ NMR (DMSO- $\left.d_{6}\right) \delta 190.4,163.8 .162 .5,160.5 .159 .8,149.8$. $146.6,133.5,130.4 .130 .3,128.8 .125 .7,116.0,115.7 .109 .1$, 47.8 .

\section{Biological Test}

Purification of HIV-1 integrase: Recombinant human immunodeficiency virus type l (HIV-1) integrase was expressed in Escherichic coli and purified using a nickelchelated column in one-step manner, as described previously. ${ }^{15}$ Aliquots of HIV-1 integrase of $0.5 \mathrm{mg} / \mathrm{mL}$ as stock solutions were stored at $-70^{\circ} \mathrm{C}$ until used.

Oligonucleotide substrates: Two 20-mer and one 18-mer oligonucleotides whose sequences resemble the end of the U5 LTR of HIV-I viral DNA were obtained from Bioneer Inc.. namely $\mathrm{Kl} 6$ (U5 LTR, +strand). 5'-TGTGGAAAATCTCTAGCAGT-3'. KI7 (U5 LTR, -strand). 5'-ACTGCTAGAGATTTTCCACA-3'. K16-2 (U5 LTR. +strand), 5'TGTGGAAA. and ATCTCTAGCA-3'. The oligonucleotides were purified using $20 \%$ polyacrylamide gel before use. In order to construct the substrate for endonucleolytic reaction, the oligonucleotide $\mathrm{K} 16$ of $50 \mathrm{pmol}$ was labeled at the $5^{\prime}$ end, using of $50 \mu \mathrm{Ci}\left[\gamma^{32} \mathrm{P}\right]-\mathrm{ATP}\left(3,000 \mathrm{Ci} / \mathrm{mm}^{2} \mathrm{l} ; \mathrm{l} \mathrm{Ci}=37\right.$ GBq; Amersham Life Science, Illinois. U.S.A.) and T4 polynucleotide kinase (T4 PNK, New England Biolabs, Beverly. Massachuetts. U.S.A.). The labeling reaction was subjected to $10 \mathrm{mM}$ EDTA. and heated to $75^{\circ} \mathrm{C}$ for $15 \mathrm{~mm}$ to inactivate T4 PNK. After addition of complementary oligonucleotide $\mathrm{K} 17$ of $60 \mathrm{pmol}$, the reaction mixture was boiled for $3 \mathrm{~min}$ and cooled down slowly. Labeled substrate was separated from unincorporated nucleotide by passage through a Biospin 6 (Bio-Rad. Hercules, Califonia, U.S.A.). The substrate for strand transfer reaction was prepared by labeling the oligonucleotide, KI6-2, with T4 PNK and $[\gamma$ 3"P]-ATP. The labeled Kl6/-2 was annealed with the complementary oligonucleotide $\mathrm{K} 17$. The subsequent procedures are same as described above.

In vitro assay: A standard assay for strand transfer activity was carried out in the presence of potential inhibitor containing $0.1 \mathrm{pmol}$ of duplex oligonucleotide substrate (K16-2/K17) and 15 pmol of HIV-1 integrase in $15 \mathrm{mM}$ Tris- $\mathrm{HCl}$ (pH 7.4), $100 \mathrm{mM} \mathrm{NaCl}, 1 \mathrm{mM} \mathrm{MnCl}, 2 \mathrm{mM} 2-$ mercaptoethanol. $2.5 \mathrm{mM}$ CHAPS. $0.1 \mathrm{mM}$ EDTA, $0.1 \mathrm{mM}$ PMSF, $1 \%$ glycerol, and $10 \mathrm{mM}$ inidazole in a total volume of $10 \mu \mathrm{L}$. Inhibitors or drugs are initially dissolved in $100 \%$ DMSO or ethanol. and added to the reaction mixture at $5 \%$ concentration of solvent in the final volume. Reaction mixtures were incubated at $37^{\circ} \mathrm{C}$ for $60 \mathrm{~min}$ and stopped by the addition of $4 \mu \mathrm{L}$ of $95 \%$ formamide, $20 \mathrm{mM}$ EDTA. $0.05 \%$ bromophenol blue, and $0.05 \%$ sylene cyanol FF. The reactions were heated to $90^{\circ} \mathrm{C}$ for $3 \mathrm{~min}$ and analyzed on a $20 \%$ denaturing polyacryamide gel. Reaction products were visualized by autoradiography of the dried gel in a phosphoimage analyzer (GS-525. Bio-Rad). The strand transfer 
activity was evaluated by studying conversion of the 18-mer oligonucleotides to the bigger ones.

Percent inhibition was calculated using the equation $100 \times$ $[1-(D-C) /(N-C)]$ where C. N. and D are the fractions of $20-$ mer substrate converted to strand transfer products for DNA alone. DNA plus integrase. and integrase plus drug. respectively. The $\mathrm{IC}_{\text {si }}$ value was determined by plotting the drug concentration versus percent inhibition and determining the concentration that produced $50 \%$ inhibition. ${ }^{16}$

Acknowledgement. T. H. Kwon and Y. J. Yoo are grateful to the Ministry of Education \& Human Resources Development for the support through the Post-BK2l program.

\section{References and Notes}

1. Barre-Sinoussi. F.: Chermann. J. C.: Rey, F: Nugeyre. M. T: Chemaret. S.: Gruest. I.: Dauglet. C.: Axler-Blin. C.: VezinetBrum, F: Rouziols. C.: Rozenbalm. W.: Montagnier. L. Science 1983, 220,868

2. Zhang. X: Neamati. N.: Lee, Y. K:: Orr. A.: Brown. R. D.: Whitaker. N.: Pommier. Y: Burker. T. R.. Jr. Bioorg. Med. Chem. 2001. 9. 1649 .

3. Brown, P. O. Curr. Top Microbiol Immmol 1990. 157, 19

4. Sakai, H: Kawamura, M: Sakuragi. T.: Sakuragi, S: Shibata. R.: Isimoto. A.: Ono. N.: Ueda, S.: Adachi. A. J. Thol 1993. 67. 1169.

5. Taddeo. B.: Haseltine, W. A.: Fannet, C. M. J. Ifrol. 1994, 69. 8401.

6. Engelman. A.: Englund. G: Orenstein. J. M.: Martin. M. A.: Craigie. R. J. Virol. 1995. 69.2729.
7. Yuan1. H.: Parrill. A. L. Bioong. Hed Chent. 2002. 10. 1469

8. Pais. G. C. G.: Zhang. X.: Marchand. C.: Neamati. N.: Cowansage. K.: Svarovskiaia. E. S.: Pathak. V. K.: Tang. Y.: Nicklaus. M.: Pommier. Y.: Burke. T. R., Jr. J. Med. Chem. 2002 , 48. 3184.

9. Grobler. J. A.: Stillmock. K. A.; Hu, B.: Witmer. M. V.: Felock. P. J., Jr.; Espeseth. A. S.; Wolfe, A. L.: Eghertson, M. S.: Bourgeois. M.: Melamed. J.: Wai. T. S.: Young. S. D.: Vacea. T. P.: Hazuda. D. J. Proc Natl .Acad. Sci. LS.A. 2002.99 .6661$.

10. Zhuang. L.: Wai. I. S.: Embrey. M. W.: Fisher. T. E.: Eghertson. M. S.: Payne. L. S.; Guare, J. P.; Huff, J. R.; Felock, P. J., Jr.; Vacea J. P: Hazuda. D. J : Felock. P. Wolfe, A. L.: Stillmock, K A.; Witmer. M. V:; Mover, G; Schleif, W. A.; Gabryelski. L. J:; Leonard. Y. M.: Lynch. J. J.. Ir.: Michelson. S. R.: Young. S. D. J. Med. Chent 2003. 46.453.

11. Hazuda. D. J.: Anthony. N. T.: Gomez. R. P.: Tolly. S. M.: Wai. J. S.; Zhuang, L.; Fisher, T. E.: Embrey. M. W: Guare, J. P.. Jr: Eghertson, M. S.: Vacca, J. P.: Hu, J. R.: Felock, P. J.: Witmer. M. V: Stillmock. K. A:; Danovich, R.: Grobler, J.: Miller, M. D: Espeseth. A. S.: Jin. L.: Chen. I.-W.: Lin. J.: Kassahuin. K.: Ellis. J. D.: Wong. B. K.: Xu. W.: Pearson. P. G.: Schleif. W. A.: Cortese. R.: Emini. E.: Summa. V.: Holloway. M. K.: Young. S. D. Proc. Katl Acad Sci. US.A. 2004, 101. 11233 .

12. (a) Lee. J. Y.: Yoon, K. J.: Lee. Y. S. Bioorg Hed. Chem. Latt. 2003. 13. 4331. (b) Lee, S. U.; Park. J. H.: Lee, J. Y.: Shin, C.-G.; Chung. B. Y.: Lee. Y. S. Bull. Kor Chent Soc. 2006. 27. 1888.

13. (a) Dejardin. I. V: Lapiere. C. L. Bulletin de la Societe Chimique de France 1979. 2(5-6). 289. (b) Lapiere. C. L:: Dejardin. J. V: Barbara, R. M. U.S. Pat. 3.912,248 (November 11, 1975).

14. Lang. S. A. Jr.: Cohen. E. J. Org. Chem. 1974, 39. 1008.

15. Oh. J.-W.: Shin. C.-G. M fol Cells 1996, 6,96.

16. Mazumder. A.: Uchida. H.: Neamati. N.: Sunder. S.: Wickstrom. E.: Zeng. F.: Tones. R. A.: Mandes. R. F.: Chenault. H. K.: Pommier. Y. Holecular Phamacology 1997.51.567. 